\title{
Maternal, Obstetric, and Infant Factors and Their Association with the Risk of HIV Infection in Infants at Dr. Moewardi Hospital, Surakarta
}

\author{
Deni Nur Fauzia Rahmawati'), Supriyadi Hari Respati'), Diffah Hanim³) \\ 1)Masters Program in Public Health, Universitas Sebelas Maret \\ 2)Department of Obstetrics and Ginecology, Dr. Moewardi Hospital, Surakarta \\ 3)Faculty of Medicine, Universitas Sebelas Maret
}

\begin{abstract}
Background: Incidence of HIV infection by mother to child transmission has been increasing for the past few years. This study aimed to determine the association between maternal, obstetric, infant factors, and the risk of HIV infection in infants.

Subjects and Method: This was an analytic observational study using case control design. This study was conducted at Dr. Moewardi Hospital, Surakarta. A total of 68 study subjects, consisting of 34 HIV infected infants, and 34 non HIV infected infants, were selected for this study by fixed disease sampling. The dependent variable was HIV infection. The independent variable included maternal nutritional status, opportunistic infection, antenatal care, type of labor, birth weight, and prematurity. The data were collected from a set of questionnaire and analyzed using logistic regression model.

Results: Maternal HIV opportunistic infection $(\mathrm{OR}=10.09 ; 95 \% \mathrm{CI}=1.99$ to $51.20 ; \mathrm{p}=0.005)$ and pervaginam labor $(\mathrm{OR}=5.21 ; 95 \% \mathrm{CI}=0.92$ to $29.58 ; \mathrm{p}=0.063)$ increase the risk of HIV infection in infant, and they were statistically significant. Maternal body weight $(\mathrm{BMI}<18.5)(\mathrm{OR}=2.71 ; 95 \%$ $\mathrm{CI}=0.44$ to $16.53 ; \mathrm{p}=0.280)$, antenatal care $<4$ times $(\mathrm{OR}=1.94 ; 95 \% \mathrm{CI}=0.42$ to $9.00 ; \mathrm{p}=0.395)$, birth weight $<2,500 \mathrm{~g}(\mathrm{OR}=1.09 ; 95 \% \mathrm{CI}=0.19$ to $6.05 ; \mathrm{p}=0.924)$ and prematurity $(\mathrm{OR}=1.65 ; 95 \%$ $\mathrm{CI}=0.36$ to $7.61 ; \mathrm{p}=0.523$ ), each increased the risk of HIV infection but statistically nonsignificant.

Conclusion: Maternal HIV opportunistic infection and pervaginam labor are strong and significant predictors for the risk of infant HIV infection. Health personnel should pay special attention on these significant risk factors when assisting birth delivery, in order to prevent HIV infection in infants.
\end{abstract}

Key words: maternal, obstetric, infant risk factors, HIV infection.

\section{Correspondences:}

Deni Nur Fauzia Rahmawati. Masters of Public Health Program, Universitas Sebelas Maret, Jl. Ir. Sutami 36A, Surakarta, 57126. Email: denierahmawati@gmail.com

\section{BACKGROUND}

$\overline{\text { Human Immunodeficiency Virus (HIV) is a }}$ retrovirus that infects cells of the human immune system (especially CD4 positive Tcells and macrophages the major components of the cellular immune system), and destroys or disrupts its function. This viral infection results in a persistent decline in the immune system, which will lead to immune deficiency (Hoyle, 2006). HIV infection in pregnancy is closely related to complications in pregnant and maternal women. HIV infection is associated with a substantial and adverse pregnancy outcome that is the maternal death with high CD4 cell counts, even with the availability of antiretroviral. Maternal mortality rates have been reported to be five times higher in HIV-infected women than in uninfected women. This account for $20 \%$ of all deaths is due to direct obstetric causes. The latest data also shows an increase in HIV 
transmission during pregnancy is women's risk caused by her partner, so pregnancy is a risk factor for HIV (Gray, 2007). Transmission of HIV from mother to child can be prevented by the intervention of Prevention of Mother-to-Child Transmission of HIV (PMTCT). Developing countries or poor countries lack access to interventions so that the risk of transmission increased to $25 \%-45 \%$. Although various efforts have been implemented over the years, the coverage of PMTCT services is still low, at $10 \%$ in 2004, increasing to $35 \%$ in 2007 and $45 \%$ in 2008.

In 2010, the coverage of PMTCT services in Indonesia is only 6\%. In order for the mother-to-child transmission of HIV to be suppressed, it is necessary to increase service coverage in line with the improvement of PMTCT program implementation (Kemenkes, 2012). Prevention of Mother to-Child Transmission of HIV (PMTCT) is very effective and has great potential to improve maternal and child health. In 2001, the United Nations General Assembly set targets for $80 \%$ of pregnant women and their children have important access to prevention, treatment, and care until 2010 to reduce the proportion of HIV-infected infants by $50 \%$. The PMTCT guidelines introduce a number of innovative treatments on infants to reduce infections, such as exclusive breastfeeding, with the aim of improving ARV access for pregnant women, women and children (WHO, 2010).

Antiretroviral therapy (ART) is now widely available in hospitals, treatment significantly improves the physical function and sexual activity of HIV-infected patients. The prospect of pregnancy and having an HIV-negative baby will be significantly increased by the increased availability of antiretroviral, due to their association with reduced risk from mother to child or vertical HIV transmission. This can lead to an increased incidence of pregnancy among HIV-infected women (Kabaddi, 2014). Efforts to prevent the spread of HIV from mother to child, comprehensive prevention program were implemented, including four strategies, namely prevention of HIV transmission in women of reproductive age. A comprehensive prevention program includes four strategies: prevention of HIV transmission in women of reproductive age is conducted as an effort to prevent motherto-child transmission of HIV.

The four strategies are unplanned pregnancy prevention in HIV-positive women, prevention of HIV transmission from HIV-positive pregnant women to their babies, psychological support, social support and care to HIV positive mothers and children and their families (Mofenson, 2010). The report of the Director General of Disease Control and Environmental Health of the Republic of Indonesia 2014 showed the highest number of HIV AIDS sufferers were housewives of 6,539 cases obtained from husbands living with HIV AIDS. The percentage of HIV AIDS infants as large as $0.4 \%$ is obtained from the maternal vertical transmission. Report on the number of HIV sufferers in RSUD Dr. Moewardi Surakarta in 2012, inpatient and outpatient as much as 207 cases, in 2013 as many as 164 cases, in 2014 as many as 198 cases. Unplanned housewife pregnancy can be vertically transmitted to her baby. Therefore, to reduce the rate of vertical transmission, then the introduction of the most dominant maternal, obstetric and infant risk factors is very important.

\section{SUBJECTS AND METHOD}

\section{Study Design}

This was an analytical observational study with a case control design. The study was conducted at Dr. Moewardi Hospital, Surakarta, from April to June 2016. 


\section{Population and Sampling}

The study population was HIV positive mothers who came to the VCT Clinic. Study subjects were 68 people, 34 HIV positive mothers with HIV positive infants (case group) and 34 HIV positive women with HIV negative infants (control group). Samples were selected by using exhaustive sampling.

\section{Study Variabel}

The dependent variables were HIV positive infants and the independent variables were nutritional status during pregnancy, opportunistic infectious diseases, ANC visits, obstetric risk factors (type of labor), and infant risk factors (birth weight and prematurity). The measuring tool used was a questionnaire.

\section{Data Analisys}

Data were analyzed using univariate and bivariate with chi square test. Multivariate analysis with multiple logistic regression test used SPSS 22 (Murti, 2013).

\section{$\frac{\text { RESULTS }}{\text { 1. Univariate Analisys }}$}

Based on Table 1 described the results of univariate analysis. Most of the mothers had good nutritional status (67.6\%), did not experience opportunistic infection (63.2\%), performed ANC $\geq 4$ times (80.9\%), and gave birth to caesarean section as many as 58 people (85.3\%) and 10 people (14.7\%) gave birth per vaginam. Most infants were born with normal birth weight (63.2\%) and term (72.1\%).

\section{Multiple Logistic Regression}

Table 3 described the results of multiple logistic regression analysis. There was a positive but statistically insignificant association between nutritional status and the incidence of HIV infants. Mothers with less nutritional status were 2.71 more likely to be HIV-positive than mothers with good nutritional status $(\mathrm{OR}=2.71,95 \% \mathrm{CI}=0.44$ to $16.53 ; p=0.280$ ).

There was a positive association between women with opportunistic infections and the incidence of HIV infants. Mothers with opportunistic infectious diseases were more likely to have a 10.09 HIV infant higher than mothers without opportunistic infections (OR=10.09, 95\% $\mathrm{CI}=1.99$ to $51.20 ; \mathrm{p}=0.005$ ).

There was a positive association between mothers with ANC visits less than 4 times with the incidence of HIV-positive infants. Pregnant women with an ANC visit $<4$ times were more likely to have 1.94 HIV infants compared to women who visited $\mathrm{ANC} \geq 4$ times $(\mathrm{OR}=1.94 ; 95 \% \mathrm{CI}=0.42$ to 9.00; $p=0.395)$.

Table 1. Univariate test result of study variable

\begin{tabular}{|c|c|c|}
\hline Variable & $\mathbf{n}$ & \% \\
\hline \multicolumn{3}{|l|}{$\begin{array}{l}\text { Maternal risk } \\
\text { factors: }\end{array}$} \\
\hline \multicolumn{3}{|l|}{ Nutritional status } \\
\hline Poor $(<18.4)$ & 22 & 32.4 \\
\hline Good $\quad(\geq 18.5)$ & 46 & 67.6 \\
\hline \multicolumn{3}{|l|}{$\begin{array}{l}\text { Opportunistic } \\
\text { infections }\end{array}$} \\
\hline There is infection & 25 & 36.8 \\
\hline No infection & 43 & 63.2 \\
\hline \multicolumn{3}{|l|}{ ANC } \\
\hline$<4$ times & 13 & 19.1 \\
\hline \multirow{2}{*}{\multicolumn{3}{|c|}{ Obstetric risk }} \\
\hline & & \\
\hline \multicolumn{3}{|l|}{ factors: } \\
\hline \multicolumn{3}{|l|}{ Type of labor } \\
\hline Pervaginam & 10 & 14.7 \\
\hline Caesarean section & 58 & $85 \cdot 3$ \\
\hline \multicolumn{3}{|l|}{ Infant risk factors: } \\
\hline \multicolumn{3}{|l|}{ Baby weight } \\
\hline LBW $(<2,500 \mathrm{~g})$ & 25 & 36.8 \\
\hline Not LBW ( $\geq 2,500 \mathrm{~g})$ & 43 & 63.2 \\
\hline \multicolumn{3}{|l|}{ Prematurity } \\
\hline Premature $(<37$ weeks $)$ & 19 & 27.9 \\
\hline Aterm ( $\geq 37$ weeks) & 49 & 72.1 \\
\hline \multicolumn{3}{|l|}{ HIV Incidence } \\
\hline Positive & 34 & 50 \\
\hline Negative & 34 & 50 \\
\hline
\end{tabular}


Journal of Maternal and Child Health (2016), 1(2): 73-81

https://doi.org/10.26911/thejmch.2017.01.02.02

There was a positive association between the type of labor and the incidence of HIV infants. Mothers with vaginal delivery were more likely to have an HIV infant 5.21 times higher than in cesarean section $(\mathrm{OR}=5.21 ; 95 \% \mathrm{CI}=0.92$ to 29.58 ; $\mathrm{p}=0.063)$.

There was a positive correlation between birth weight and the incidence of HIV infants. Infants of low birth weight
$<2.500 \mathrm{~g}$ had a probability of experiencing HIV 1.25 times higher than in normal-weight babies $(\geq 2,500 \mathrm{~g})(\mathrm{OR}=1.0995 \% \mathrm{CI}=$ 0.19 to $6.05 ; \mathrm{p}=0.924)$.

There was a positive correlation between birth weight and the incidence of HIV infants. Infants born with prematurity had an estimated HIV of 1.65 times higher than infants born at term $\geq 37$ weeks $(\mathrm{OR}=1.65$; $95 \% \mathrm{CI}=0.36$ to $7.61 ; \mathrm{p}=0.523)$.

Table 2. Bivariate test of maternal risk factors with the incidence of HIV infants

\begin{tabular}{|c|c|c|c|c|c|c|}
\hline \multirow[b]{2}{*}{ Variable } & \multicolumn{2}{|c|}{ Infant HIV Status } & \multirow[b]{2}{*}{ OR } & \multicolumn{2}{|c|}{$95 \%$ CI } & \multirow[b]{2}{*}{$\mathbf{p}$} \\
\hline & $\begin{array}{c}\text { Positive } \\
\text { N (\%) }\end{array}$ & $\begin{array}{c}\text { Negative } \\
\mathbf{N}(\%)\end{array}$ & & $\begin{array}{c}\text { Lower } \\
\text { limit }\end{array}$ & $\begin{array}{c}\text { Upper } \\
\text { limit }\end{array}$ & \\
\hline \multicolumn{7}{|c|}{ Maternal risk factors: } \\
\hline $\begin{array}{l}\text { Poor }(<18.4) \\
\text { Good }(\geq 18.5)\end{array}$ & $\begin{array}{l}18(81.8 \%) \\
16(34.8 \%)\end{array}$ & $\begin{array}{c}4(18.2 \%) \\
30(65.2 \%)\end{array}$ & 0.12 & 0.03 & 0.41 & $<0.001$ \\
\hline \multicolumn{7}{|c|}{ Opportunistic infections } \\
\hline $\begin{array}{l}\text { Yes } \\
\text { No }\end{array}$ & $\begin{array}{l}21(84.0 \%) \\
13(30.2 \%)\end{array}$ & $\begin{array}{c}4(18.2 \%) \\
30(12.5 \%)\end{array}$ & 0.08 & 0.02 & 0.29 & $<0.001$ \\
\hline \multicolumn{7}{|l|}{ ANC } \\
\hline $\begin{array}{l}<4 \text { times } \\
\geq 4 \text { times }\end{array}$ & $\begin{array}{l}7(53.8 \%) \\
27(49.1 \%)\end{array}$ & $\begin{array}{c}6(46.2 \%) \\
28(50.9 \%)\end{array}$ & 0.83 & 0.25 & 2.78 & 0.758 \\
\hline \multicolumn{7}{|c|}{ Obstetric risk factors: } \\
\hline $\begin{array}{l}\text { Pervaginam } \\
\text { Caesarean section }\end{array}$ & $\begin{array}{c}7(70 \%) \\
27(46.6 \%)\end{array}$ & $\begin{array}{c}3(30 \%) \\
31(53.4 \%)\end{array}$ & 0.37 & 0.09 & 1.59 & 0.171 \\
\hline \multicolumn{7}{|l|}{ Infant risk factors: } \\
\hline $\begin{array}{l}\text { LBW }(<2,500 \mathrm{~g}) \\
\text { Not LBW }(\geq 2,500 \mathrm{~g})\end{array}$ & $\begin{array}{l}19(76.0 \%) \\
15(34.9 \%)\end{array}$ & $\begin{array}{c}6(12.5 \%) \\
28(65.1 \%)\end{array}$ & 0.17 & 0.06 & 0.51 & 0.001 \\
\hline \multicolumn{7}{|l|}{ Prematurity } \\
\hline $\begin{array}{l}\text { Preterm }(<37 \text { weeks }) \\
\text { Term }(\geq 37 \text { weeks })\end{array}$ & $\begin{array}{l}12(63.2 \%) \\
22(44.9 \%) \\
\end{array}$ & $\begin{array}{l}7(36.8 \%) \\
27(55.1 \%) \\
\end{array}$ & 0.48 & 0.16 & 1.41 & 0. 177 \\
\hline
\end{tabular}

Table 3. Multiple logistic regression of the association between maternal, obstetric, infant risk factors, and the incidence of HIV in infants

\begin{tabular}{lcccc}
\hline \multicolumn{1}{c}{ Independent Variables } & \multirow{2}{*}{ OR } & \multicolumn{2}{c}{ 95\%CI } & \multirow{2}{*}{ p } \\
\cline { 3 - 4 } & & Lower limit & Upper Limit & \\
\hline Maternal nutritional status (BMI <18.5) & 2.71 & 0.44 & 16.53 & 0.280 \\
Opportunistic infection (infection) & 10.09 & 1.99 & 51.20 & 0.005 \\
ANC (<4 kali) & 1.94 & 0.42 & 9.00 & 0.395 \\
Type of labor (pervaginam) & 5.21 & 0.92 & 29.58 & 0.063 \\
Birth weight (<2500 g) & 1.09 & 0.19 & 6.05 & 0.924 \\
Prematurity (<37 weeks) & 1.65 & 0.36 & 7.61 & 0.523 \\
n observation=68 & & & & \\
-2 Log likehood=67.255 & & & & \\
Nagelkerke R Square = 43.7\% & & & \\
\hline
\end{tabular}

Based on the results of multivariate analysis in Table 3, it can be concluded that from the variables tested, the acquisition of opportunistic illness infection factors significantly influenced the incidence of HIV infants. 


\section{DISCUSSION}

\section{The association between nutrition-} al status and hiv incidence

The results showed that the maternal nutritional status was positive but statistically insignificant with the incidence of HIV infants. Based on the results of the study, malnutrition status has the possibility of increasing the occurrence of HIV infants. The results of this study were in line with previous studies (Mehta, 2011, Lartey, 2012) indicating that low maternal nutritional status increases the risk of HIV transmission in infants.

Malnutrition in pregnant women with HIV may increase the incidence of anemia. Pregnant women with anemia are more likely to give birth to babies with low birth weight compared with the mother is not anemic, low birth weight risk 1.6 times and 4.8 times higher for children born to women with anemia. Pregnant women with anemia increase HIV transmission from mother to child (Msuya et al., 2011).

The results of this study are in accordance with other studies, studies of nutritional status associated with anemia in pregnancy and HIV infection in infants. Health education on personal hygiene and screening of HIV risk factors should be implemented.

\section{The association between oppor- tunistic infections and HIV inci- dence in infants}

The results of the study on opportunistic infections had a statistically significant positive association between maternal and opportunistic infectious diseases with the incidence of HIV infants. Mothers with infectious diseases were more likely to have a larger HIV infant compared to mothers who do not have opportunistic infectious diseases.

The results of this study were in accordance with the study Mwapasa et al.
(2012) that mentions HIV pregnant women who suffer from opportunistic infections 17.6\% deliver babies with HIV. From these results, it is recommended to implement in the prevention of mother-to-child transmission of HIV since pregnancy, by early detection of infectious diseases and treatment of infectious diseases of pregnant women with HIV.

The presence of this bacterial vaginosis infection increases 3 times the small incidence of gestation, which can lead to a 6-fold increase in the occurrence of infants with HIV also associated with premature birth. Bacterial vaginosis infections increase 3 times the small incidence of gestation. Minor pregnancy is associated with a 6-fold increase in infant HIV infections that can lead to death (Slyker et al., 2014).

The study results according to Singhal (2011), viral infection in pregnancy is the main cause of morbidity and mortality for mother and fetus. Sexually transmitted infections (STIs) caused by viruses occur as early infection and then gradually infect immunological cells. It is asymptomatic, hidden and therefore undiagnosed, persistent and difficult to treat. Common infections are HSV, HPV, HBV, HIV and CMV (cytome-galovirus). Most are transmitted during the intrapartum period. Appropriate screening, identification, and care offered during the prenatal period can help in preventing complications. Women with a history of $25 \%$ genital herpes have an infection during the last month of pregnancy. Caesarean section is recommended only if genital herpes lesions inhibit the birth canal. Transmission of HIV from mother to baby shows $15-30 \%$ during pregnancy and childbirth, and 5-20\% more transmission occurs through breastfeeding. 


\section{The association of ANC visits with the incidence of HIV infants}

The results of the ANC visit were a statistically negative association between ANC visits and the incidence of HIV infants. Mothers with an ANC visit <4 times were more likely to have a larger HIV infant compared to women who visited ANC $\geq 4$ times. Barry (2011) states the visit of ANC $<2$ visits during pregnancy, the patients do not start active antiretroviral therapy, and this has an important role in increasing HIV transmission in infants and children.

The Gondo (2011) study results are optimizing the health of HIV-positive mothers through regular ANC screening by Monitoring of the Woman and Fetus during Pregnancy. Roboransia is given to supplement the increased need for macronutrients. Healthy lifestyle, among others: enough nutrition, enough rest, enough exercise, no smoking, no drinking alcohol also needs to be applied. The use of condoms is still required to avoid the possibility of superinfection when couples are also PLWHA, or prevent transmission if the couple is not PLWHA.

According to Bianco et al. (2014) 6\% of infants have HIV infection. This occurs because of inadequate ANC and failure to receive antiretroviral drugs during pregnancy, resulting in increased viral loads and intravenous drug abuse. Increased mother to-child transmission of HIV was 3 times higher in mothers who performed ANC less than standard. Maternal to infant HIV transmission can be reduced by ensuring proper ANC access, including labor, antiretroviral therapy and narcotics use.

\section{Association between types of labor and HIV incidence in infants}

There was a positive association and it was statistically insignificant between types of labor and the incidence of HIV infants. Mothers with vaginal delivery were more likely to have a larger HIV infant compared to mothers who are in labor with cesarean section.

The results of the study from Purnaningtyas (2011) states pregnant women with HIV who did labor with pervaginam delivery, increasing the risk of transmission of HIV incidence in infants. Housewives with HIV/AIDS, in an effort to prevent HIV/AIDS transmission to their offspring, conduct self-protection by giving birth by cesarean section (Lina, 2012). This is confirmed by Gondo study (2011) that delivery with cesarean section planning before the time of delivery arrived is an option of PLWHA.

At the time of vaginal delivery, babies were exposed to blood and maternal mucus in the birth canal. The infant might also be infected by swallowing the blood or mucus of the birth canal (accidentally during resuscitation). Several studies have concluded that cesarean section will reduce the risk of mother-to-child transmission of HIV by $50-66 \%$. If caesarean section is unenforceable, it is advisable not to perform an invasive action that allows injury to the infant.

Obstetric risk factors associated with increased risk of infant HIV are pervaginary, long-acting, premature rupture, and invasive procedures or with action (Wilson et al., 2016).

American College of Obstetricians and Gynecologists (ACOG) dan U.S. Public Health Service (PHS) recommended that HIVinfected pregnant women with viral load $>1,000$ can be counseled regarding the benefits of birth by elective Caesarean section. Since the guidelines were published, cesarean section rates among HIVinfected women in the US increased dramatically. Severe birth morbidity was uncommon, and cesarean delivery among 
HIV-infected women was relatively safe and cost-effective.

\section{The association of birth weight and the incidence of HIV in infants}

The result of the study on birth weight was found to be a statistically insignificant association between birth weight and the incidence of HIV infants. Mothers of low birth weight baby have a higher probability of getting a baby with HIV than a normal birth weight baby.

The results of this study are in line with the results of the Magezi (2011). It is said that the incidence of low birth weight has a $8.4 \%$ chance of getting an HIV infant compared to a normal birth weight baby. According to Slyker et al. (2014) HIV-1 RNA levels of pregnant women are associated with an increased incidence of LBW. Infants who experience LBW increased 6 times the infection of HIV. The causes of LBW that is HIV-1 RNA and genital infection are important risk factors for premature birth with LBW in HIV infants.

\section{The association and infant premat- urity HIV incidence in infants}

The results of the study on infant prematurity have a positive association, which is statistically insignificant, between infant prematurity and the incidence of HIV infants. Infants with preterm delivery are more likely to have HIV than infants who are not premature.

The results of this study are in line with the results of Gabiano et al. (2012) studies that the rate of premature infants observed was $24 \%$ higher than that found in other HIV-infected populations. A study in the United States in early 1990 found that $19 \%$ of infants born with HIV infection came from mothers who gave birth with prematurity. Weight loss during pregnancy is associated with premature birth.

Pregnant women with HIV may experience complications of pregnancy, one of which is preterm labor that results in premature birth, infant growth retardation, stillbirth, and HIV-infected infants (Leveno et al., 2009).

Prematurity is a risk factor for the transmission of HIV from mother to child. Several studies suggest that infants born to HIV-infected mothers may be particularly vulnerable to intrapartum infections. Mothers who deliver premature babies (<34 weeks) with viral load <400 copies/ $\mathrm{ml}$ have a higher risk of HIV infection than infants with term. Elective or emergency cesarean section in premature infants is associated with an increased risk of mother-to-child transmission of HIV (Throne et al., 2011).

Babies born prematurely from HIVinfected women have higher rates of HIV infection than those of mature babies (Wilson et al., 2016). From this study it can be concluded that infectious diseasecausing infections are significantly different with the incidence of HIV infants.

This study suggests that families should provide assistance to pregnant women with HIV in order to have awareness of taking care of themselves by doing the ANC and implement the advice of a doctor or counselor, improve prevention of mother-to-child transmission of HIV through the dissemination of information such as poster leaflets, thus providing information to all layers of the community and implementing HIV testing programs for every pregnant woman. The need for further study on other factors that may affect the occurrence of HIV transmission in infants and other analyzes such as path analysis.

\begin{tabular}{c}
\hline REFERENCES \\
\hline $\begin{array}{c}\text { American College of Obstetrics and Gynec- } \\
\text { ology (ACOG) Practice bulletin } \\
\text { (2010). }\end{array}$
\end{tabular}


Cesarean Delivery. Clinical Management Guidelines for Obstetrician-Gynecologist. No.115.

Barry OM, Anne MB, Jennifer DM, Elise E, Trace SK, Brian WCF (2011). Development of Measures of The Patient-Provider Relationship in A ANC And Its Importance in PMCT. Journal AIDS care. 24 (6): 680-686.

Bianco DG, Bell CS, Benjamins LJ, Pérez, N, Rodriguez G, Murphy J, Heresi GP (2014). Persistently High Perinatal Transmission of HIV: Assessment of Risk Factors. Pediatric infectious disease journal. 33 (6): e151-e157.

Gabiano CG, Pier-Angelo T, Maunzio de M, Luisa G, Carlo G, Anna L, Mariangela CS, et al. (2012). Mother-to-Child Transmission of Human Immunodeficiency Virus Type 1 Risk of Infection and Correlates of Transmission. Pediatrics. 90(3): 369 .

Gondo, Tjokorda (2011). Ultrasonografi Buku Ajar Obstetric Ginekologi. Jakarta: EGC.

Gray GE, Mc IJA (2007). HIV and Pregnancy. BMJ. 337.

Hoyle, Brian (2006). AIDS/HIV the Information Series on Current Topics. Texas: Information Plus.

Kabami J, Eleanor T, Sam B, Francis B (2014). Increasing Incidence of Pregnancy among Women Receiving HIV Care and Treatment at a Large Urban Facility in Western Uganda. Biomed central. 11 (81).

Kemenkes RI (2012a). Survei Demografi dan Kesehatan Indonesia. Jakarta: Kemenkes RI. (2012b). Pedoman Nasional Pencegahan Penularan HIV dari Ibu ke Anak (PPIA) Edisi Kedua , Jakarta.

(2014). Peraturan Menteri Kesehatan Republik Indonesia Nomor 97 Tahun 2014 tentang Pelayanan Kesehatan
Masa Sebelum Hamil, Masa Hamil, Persalinan, dan Masa Sesudah Melahirkan, Penyelenggaraan Pelayanan Kontrasepsi, serta Pelayanan Kesheatan Seksual, Jakarta.

Lartey A (2012). Maternal and Child Nutrition in Sub Sahara Africa: Chalenges and Intervention. The nutrition society. 67(1): 105-108.

Leveno KJF, Gary C, Norman FG, James MA, Steven LB, Brian MC, Jodi SD, Jeanne SS, Nicole PY (2009). Obstetri Williams: Panduan Ringkas Edisi 21. Jakarta: EGC.

Lina RK (2012). Upaya Pencegahan Transmisi dari Ibu ke Anak pada Ibu Rumah Tangga Penderita HIV/AIDS di Kota Yogyakarta. Electronic Dissertations Gadjah Mada University.

Magezi SR, Joyce K, Roger W (2011). Feeding and Nutritional Characteristics of Infants on PMTCT Programs. Oxford Journals. 55(1): 32-35.

Mehta S, Karim PM, Alicia MY, Elizabeth B, Charles C, Taha ET, Jennifer RR, Robert (2011). Nutritional Indicators of Adverse Pregnancy Outcomes and Mother TCT of HIV among Infected Women. Am j clin nutr. 87(6): 16391649.

Mofenson LM (2010) Prevention in Neglected Subpopulations: Prevention of Mother-to-Child Transmission of HIV Infection. Clinical Infectious Diseases. Oxford journals. 50(3): S130-S148.

Msuya SE, Tamara HH, Jacqueline U, Noel ES, Babill SP (2011). Anaemia among Pregnant Women in Northern Tanzania: Prevalence, Risk Factors and Effect on Perinatal Outcomes. Tanzania Journal of health Research. 13(1).

Murti B (2013). Desain dan Ukuran Sampel untuk Penelitian Kuntitatif dan Kualitatif di Bidang Kesehatan. Yogyakarta: Gajah Mada University Press. 
Mwapasa V, Stephen JR, Jesse JK, Paul EW, Danny M, Malcolm EM, Deborah DK, et al. (2012). Maternal Syphilis Infection is Associated with Increased Risk of Mother-To-Child Transmission of HIV in Malawi. AIDS. 20 (14): 1869-1877.

Purnaningtyas $\mathrm{AD}$, Dewantiningrum $\mathrm{J}$ (2011). Persalinan Pervaginam dan Menyusui sebagai Faktor Risiko Kejadian HIV pada Bayi. Media Medika Indonesia.

Singhal PS, Naswa YS, Martllia (2011). Pregnancy and Sexually Transited Viral Infecion. Indian Journal of Sexually Transmitted Diseases and AIDS. 30(2): 71-78.

Slyker JA, Janna P, Gwen A, Barbara AR, Elizabeth MO, Rose B, Dorothy MN, Carey F, Grace JS (2014). Correlates and Outcomes of Pretrem Birth, Low Risk Weight and Small for Gestational Age in HIV-exposed Infected Infants. BMC Pregnancy and Childbirth. 14:7.

Throne C, Boer K, Godfried MH (2012). Mode of delivery in HIV-infected pregnant women and prevention of mother-to-child transmission: changing practices in Western Europe. Europe PMC Funders Group. 11(6): 368-378.

WHO (2010). PMTCT Strategic Vition 2010-2015 Preventing mother-to-child transmission of HIV to reach the UNGASS and Millennium Development Goals. Geneva: WHO.

Wilson CB, Victor N, Yvonne M, Jerome OK, Jacks R (2016). Remington and Kleins Infectious Disease of the Fetus and Newborn Infant. Elsevier Saunders, 8. 